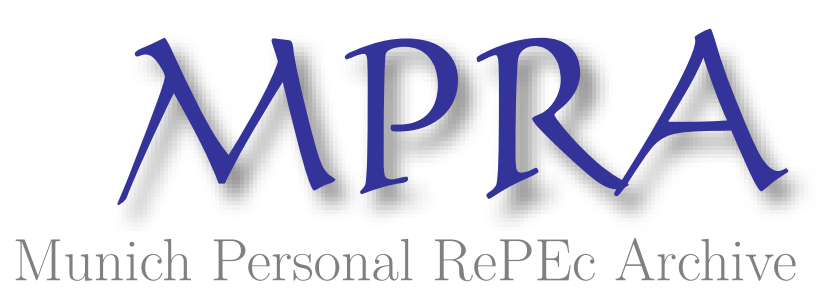

\title{
Will India become a world economy power?
}

Incaltarau, Cristian

1 August 2010

Online at https://mpra.ub.uni-muenchen.de/28658/

MPRA Paper No. 28658, posted 09 Feb 2011 09:23 UTC 


\section{WILL INDIA BECOME A WORLD ECONOMY POWER?}

Abstract: India's economic rise during the last decades has surprised most of the economists, including the Nobel Laureate Paul Krugman. Which are the ingredients of such an economic roadmap and why hasn't India's economy boosted along with those of the "Asian tigers" during the 80s or later, with China's economy?

Once India became an important economic player, it can no longer be neglected in international political relations as the struggle for world supremacy became more an economic and technological competition, military rivalry going in the background. How can India maintain growth rates at such a high level? What are the prospects regarding economic and political relations between India and China?

Keywords: India, China, economic power, world economy, knowledge economy, human capital JEL Classification: F02, F59, O53

\section{India's place in world economy}

With about 1.2 billion inhabitants, India is the second country worldwide in terms of population and the seventh large geographical area, having a population density even higher than that of China (The World Factbook). If this geographical description sounds impressive, the economic data are not far behind. During 2003-2008, India witnessed an average growth rate of 8.8\%. Even Nobel Laureate Paul Krugman confirmed that he had been surprised by the rapid growth of Indian economy. Regarding this fact he said: "we know nothing about India" (Krugman, 2007). The question that arises is whether India will be able to maintain high levels of growth and whether it will boost India as an economic power in the global economy?

The spectacular economic rises of countries in Eastern and South-East Asia, in the past 40 years, cannot be explained by an isolated, regional analysis. That was the result of international specialization that has led to the integration of Asia's labor surplus in main international trade flows. Since the early '60s, increased international trade was based on the relocation of laborintensive activities to countries which had plenty of manpower and the costs of its use were much lower (Guha, 1996, cited in Guha and Ray 2004:299-300). Worldwide there have been changes towards trade liberalization, since Kennedy Round of negotiations from the early '60s, culminating with the establishment of World Trade Organization in 1990. If, initially, developing countries could not benefit from economies of scale and the low cost of labor advantages were abolished by trade barriers and transport costs, starting with the trade liberalization, economies of scale began to matter less.

Asia, or rather the countries whose economy was opened in Asia (initially East Asia then, in the 80s, South Asia as well), were the main beneficiaries of global trade liberalization. East Asia 
embraced the development path ahead of South Asia thanks to some advantages: it was closer to the most economically prosperous regions (California and Japan); it had access to shipping (one of the cheapest means of transport); Confucian religion provided a relatively higher level of education compared to other religions.

Developing countries in Asia followed the "theory of development after the flight of wild geese" developed by Akamatsu in 1962. The original leader was Japan, followed by the "Four Tigers" (Korea, Taiwan, Hong Kong and Singapore), the "Three Cubes" (Indonesia, Malaysia and Thailand) and, finally, China and Vietnam. Each of these groups starting with Japan have registered rapid growth and increasing wages. Labor-intensive activities were relocated to the lower group, where labor costs were lower while the higher group focused on more sophisticated tasks that required a more advanced technological level (Guha and Ray 2004: 301).

The developing countries from Asia followed the "theory of economic development after the flight of wild geese" developed by Akamatsu in 1962. The original leader was Japan, followed by the "Four Tigers" (Korea, Taiwan, Hong Kong and Singapore). The following were the "Three Cubes" (Indonesia, Malaysia and Thailand) and, finally, China and Vietnam. Each of these groups, starting with Japan, have registered rapid growth and increasing wages. Labor-intensive activities were relocated to the lower group (less developed countries), where labor cos ts were lower, while the higher group were focusing on more sophisticated tasks that required a more advanced technological level (Guha and Ray 2004: 301).

India missed the opportunity to position itself in one of the leading places in the world economy with industrialized countries in Asia like South Korea, Taiwan, Hong Kong or Singapore in the 80s or later, along with Malaysia, Indonesia and Thailand in the 90s. It, however, managed to catch the third wave along with China and other smaller countries like Vietnam.

Opening of the Indian economy has been achieved later, forced by the 1991 crisis (the fiscal imbalances caused by the crisis determined the Indian currency appreciation and an increased balance of payments deficit). Along with China, which already in the '90s was recording fulminating growth rates, India was able to provide, in turn, cheap labor. Indian government's efforts to create a large middle class, educated, by investing in science and technology, had to show results later on, when, combined with historical experience, which has facilitated a wide knowledge of English, has determined a successful development in information technology field (IT). Thus, if China has specialized in exports of traditional products intensive in labor, India has developed in areas with a higher degree of technology like programming and IT, biotechnology, pharmaceutical and distance telecommunications services (Guha and Ray 2004:301 - 302).

As we said earlier, India liberalized international trade only 20 years ago, thanks to 1991 reforms. Trade liberalization fosters economic development through multiple channels. First, the expansion of trade in foreign markets it increases productivity through economies of scale 
appearance in the export sector. Export revenues provide the amounts needed for the import of materials needed for domestic production. Exports have a positive impact on production, leading to a better allocation of resources through international specialization based on comparative advantages. Not least, international competition stimulates technological progress and improved management of firms, which generates positive effects on the whole economy.

"The New Economic Policy (NEP) or "The New Industrial Policy" introduced in July 1991 led to the withdrawal of state from many economic activities, including controlling the production system. Moreover, they made the decision to privatize, gradually, state enterprises and to liberalize foreign trade. Here are some of NPE measures regarding foreign trade, investment and technology transfer (Kaplinsky, 1997, Ghosh, 1997, cited in Park, 2002:74):

- Devaluation of the rupee by 18 percent in an effort to make Indian exports more competitive;

- Significant relaxation of the restrictions on the inflow of foreign capital and technology transfer; for 34 industries foreign equity investment was allowed up to 51 percent;

- Elimination of import quotas on raw materials, intermed iate and capital goods;

- Sharp reduction in tariffs - from the peak rate of 200 percent in 1990 to 65 percent in 1994 with the average rate of nominal tariff being more than halved during 1990-94;

- Placing an increasing number of consumer goods on OGL (open general license);

- Simplifying the system of exchange controls, thereby establishing a partial convertibility of the rupee.

Reforms in India had to produce remarkable results. Indian economy has grown an average of 5.3\% per year during 1978-2003 and 8.8\% during 2003-2008 (Samantaraya and Verrier, 2009:203). The highest rate of real growth after 2000 was reached in 2006 (9.8\%). Then, rates began to decrease, reaching 9.4\% in 2007 and $7.3 \%$ in 2008. Despite the global economic crisis in 2009, real GDP growth reached 5.7\% and is estimated at 9.7\% in 2010 (Global Finance Magazine).

India's exports have witnessed a fast growth. If the average growth rate of exports amounted to $8.5 \%$ during $1995-2001$, it had to reach $28.1 \%$ in January-August 2004 compared with same period of 2003 (IMF, 2002, 2004, 2005, Bhatt, 2008:251). During the period 2004-2007, India's services exports raised with 128\% and merchandise exports with 90\% (IMF 3008, in EximBank, 2008). Moreover, according to WTO India's share in world trade touched $1.5 \%$ in 2006.

Regarding the geographical spread of Indian exports, developing countries still remained the main destination. The most important market for Indian products is the U.S., although the percentage has dropped considerably in recent years. The general trend is, however, to redirect from developed countries to developing countries, where the percentage of exports rose from $5.5 \%$ during 1987-1990 to 40\% during 2005-2008. Another important aspect is the increase of exports to China, which is becoming an important market for Indian products (Directorate General of Commercial Intelligence and Statistics, in Singh, 2009:154). 
The evolution of geographical orientation of imports is similar to that of Indian exports, namely a decrease in imports from certain developed countries (including the U.S., which was the main partner) and an increase in imports from developing countries. Another important aspect is the intensification of trade relations with partners in Asia, especially China, after 2000. China has already become the leading exporter to India (Directorate General of Commercial Intelligence and Statistics, in Singh, 2009:157).

Table 1 - Technology Inte nsity of India's Exports

\begin{tabular}{lcccr}
\hline & $1990-91$ & $1995-96$ & $2000-01$ & $2005-06$ \\
\hline High technology & 4.1 & 4.0 & 4.8 & 4.6 \\
Medium-high technology & 13.1 & 12.1 & 13.9 & 16.7 \\
Medium-low technology & 29.5 & 30.2 & 33.5 & 46.4 \\
Low technology & 47.2 & 47.8 & 42.1 & 28.9 \\
\hline
\end{tabular}

Source: Directorate General of Commercial Intelligence and Statistics în Singh, 2009:152;

Following the technological intensity of India's exports, we can observe the diminishing percentage of less advanced technologies, with low added value, and the tendency to redirect towards exports of medium and even high technology.

\section{India's role in international political relations}

India can no longer be neglected in international economic relations. U.S. wants to turn India into a long term partner that will defend their interests and values. India agrees with this relationship as long as it serves its economic and strategic interests. There are disputes, especially in the WTO, where the U.S. is accused of nepotism and the granting of subsidies in agriculture. Also, India is opposing to U.S. influence against China (which it considered to be the main economic rival) and Iran. However, $66 \%$ of Indians have a favourable opinion about China and only $56 \%$ see a threat in China's military modernization (Jaffrelotm, 2009).

The most delicate problem remains the provision of energy sources, for which India does not hesitate to work with worldwide excluded countries, such as Sudan, Myanmar (which will be linked to India through a pipeline which will supply natural gas). India does not even hesitate to work with Iran, which the U.S. seeks to isolate it, because of its nuclear weapons program. State-owned Indian Oil Corporation has signed a contract with the Iranian company Petropars to exploit the richest natural gas reserves currently known in Pars. Even more, India offers assistance in building a deep sea port in Chabahar, which will compete with Dwadar, in Pakistan; the cooperation with Iran aims, in particular, to overcome the technological equipment of Russia, since Russia is not too advanced in the construction of submarines for warmer waters (Jaffrelotm, 2009:12). 
In 2003, on Brazil's initiative, Brasilia Declaration was signed between India, Brazil and South Africa. As a result, IBSA was created, a strategic partnership between the three developing countries, which has proposed to (Hirst, 2008):

- represent the emerging countries in the debate on globalization;

- be part of the G-8;

- promote diplomacy as the main way to collaborate between countries;

- reinforce the role of development cooperation in negotiations on international agendas;

- represent the voice of developing countries in multilateral forums (UN, IMF, WB).

But will India give up cooperation with Iran if the U.S. asks it? Tensions within U.S. - India relationship, related to the WTO or the attitude towards Iran and China will be difficult to repair if amplify. Despite these disagreements, economic relations between India and China are close. In addition, in U.S. there are over 80,000 Indian students, more than any other nationality, and over 3 million people of Indian origin. This favours the creation of a "human bridge" between the two countries (Feigenbaum, 2008).

\section{Knowledge economy - the key to world powe $\mathrm{r}$ status}

The new economies are innovation based, with technology development as the main component, leading to a high level of competitiveness and human development. This can be achieved only through education. The contribution of education to economic growth lies primarily in providing new knowledge provided by scientists. Second, this knowledge is passed on and explained as well through education. Developing a knowledge economy is the more important the larger population gets. As far as I concern, this is the way for becoming global powers for countries with huge population, like India and China. Moreover, Yash Pal, former Chairman of UGC (University Grants Commission of India), said in 2008 that one of the most important reasons for the current mess in the world is the improper functioning of universities (cited in Narasimharao, 2009:143).

India has a huge potential to become a world leader in knowledge economy. However, this cannot be done easily. The most important role is held by the universities as centers that generate and spread knowledge. Kothari Commission ${ }^{1}$, in 1966, concluded that the Indian education system must be reformed or refocused. Offering the Kothari Commission's Report to Minister of Education, MC Chagla, DS Kothari (1966, cited in Agrawal, 2007:554) said:

"It is characteristic of a world permeated by science that in some essential ways the future shape of things is unpredictable. This emphasises all the more the need for an educational policy which

\footnotetext{
${ }^{1}$ Kothari Commission (1964-1966) was appointed by the Government of Ind ia to examine the conditions of service of teachers, in order to improve Indian education standards;
} 
contains a built-in flexibility so that it can adjust to changing circumstances. It underscores the importance of experimentation and innovation." He added, “...the single most important thing needed now is to get out of the rigidity of the present system. In a rapidly changing world of today, one thing is certain: yesterday's educational system will not meet today's, and even less so, the need of tomorrow."

India has institutions that offer a high quality education. In 1951, Jawaharlal Nehru, Prime Minister of India, established the first of the seven Indian Institutes of Technology (IIT). Hundreds of thousands of Indian students race to be admitted and graduate from these institutes. They have become islands of excellence, not allowing the general degradation of the Indian education system. Given India's population, which exceeds 1 billion people, this competition has given rise to a phenomenal meritocracy based on knowledge (Friedman, 2007).

It is remarkable that a developing country has realized and anticipated the importance of human capital, not to mention that it has one of the highest populations in the world. India's orientation towards education continuated with Sam Pitroda ${ }^{2}$ s s statement at the Fifth International Conference CALIBER ${ }^{3}$ (2007), when he admitted the actuality of Kothari Commission's Report recommendations: "No reforms are more important and more urgent than to transform education to endeavour to related to life, needs and aspirations of the people and thereby make it a powerful instrument of social, economic, and cultural transformation necessary for realisation of our National goals." (cited in Narasimharao, 2009:123-124).

The introductory note of the National Knowledge Commission in India confirms this view regarding the importance of education: "It is clear that the system of higher education in India faces serious challenges. And it needs a systematic overhaul, so that we can educate much larger numbers without diluting academic standards. This is imperative because the transformation of economy and society in the twenty-first century would depend, in significant part, on the spread and the quality of education among our people, particularly in the sphere of higher education. It is only an inclusive society that can provide the foundations for a knowled ge society" (in Narasimharao, 2009:124).

In today's societies, characterized by an accelerated rate of progress and change, it becomes necessary to change the education system as well. But India's reformist vision of linking education with the reality needs, to increase the number of students without reducing the quality of education, it sounds very nice. I think these are, or should be, the objectives of any ministry of education from any country. But that's not as easy as it sounds. First, universities must get out of traditional thinking, bounded by a certain framework and to establish close relations with the knowledge needs of postindustrial society. Unlike developed countries, developing countries lack of adequate economic structures that generate links between state, industry and education (Krishna et al., 2000).

\footnotetext{
${ }^{2}$ Sat Pitroda is the chairman of National Knowledge Commission of India;

${ }^{3}$ Convention on Automation of Libraries in Education and Research Institutions
} 
Secondly, the state, along with leading institutions (such as University Grants Commission of India, India Council for Technical Education and the Council for Scientific and Industrial Research), must change its approach and policies with clear objectives to build an inclusive society. This will acknowledge that learning organizations must be built on excellence and cooperation, which cannot be imported through the inorganic components and artifacts, nor through control mechanisms or through practices that have worked in other physical and social environments. Third, universities must be released by interferences and transformed in real centers of knowledge, even they may make mistakes. Fourth, there should be found ways to use universities as a whole and to incorporate many recent discoveries. Universities are the best strategies for integration through collaboration and cooperation by including various concepts such as distance learning, corporate universities, extension education, adult education, community empowerment, university-industry interactions and so on. It is therefore necessary to break traditional rigidities and limitations.

Particularly important is that the change to occur from within and not by external rules. The two main categories of society (community and industry / business organizations) should work in close association with universities. The notion of partnership should be etched in academia to enable participation of local and national authorities, community authorities, non-governmental organizations, international agencies, local small and medium-sized enterprises and local universities for the successful development of a regional knowledge economy (Narasimharao, 2009).

\section{Prospects for India's economic and political role worldwide}

India's potential on the continuation of rapid economic growth and poverty reduction can't be exploited until the following key issues are fully accomplished (Bottelier, 2007:131-132):

- Expanding rapidly as possible the relatively narrow economic base, which was the basis for economic growth in recent years. Since the development of manufacturing output is essential for increasing employment and agriculture for poverty reduction practice, this means that policies and resources should be directed in particular to manufacturing and agriculture production.

- Rapid construction of urban and rural infrastructure (including water reservoirs and irrigation facilities). As fiscal resources will not allow the recovery of the gap, is essential to mobilize more private capital, of national and foreign origin, for the infrastructure development.

-To generate resources in order to finance higher investment, especially in infrastructure, India needs to increase national saving rate, which calls for continued strengthening of the tax system as the population's savings rate is already high.

- At the political level, to reach a consensus on tax reform and greater economic liberalization, which implies the abolition of restrictions on internal and external trade and investment. Given that 
India is a large sized economy, liberalization and integration of national markets is at least as important as opening borders to trade performance.

- Attracting more foreign direct investment and allowing multinational companies to have a larger role in national retail and supply.

Regarding entrepreneurship, India recovers quickly the gap from other emerging countries like China. Small enterprises' increase exceeds the increase of both large enterprises and GDP growth. However, entrepreneurial structure remains stable. The share of registered companies has remained stable for years at a level of only 13 percent. This indicates that many entrepreneurial efforts have a low economic impact, which is limited only to ensure a decent living for the entrepreneur. Improving the quality remains the main challenge for future business. This should lead to an increase in registered companies. Where will this happen, the owners can be held accountable for their business developments and this will lead to a more formalized way of entrepreneurship. By raising the quality of entrepreneurship, it will have a substantial contribution to economic development, noting that only high-potential entrepreneurs have a positive impact on economic development (Wong, 2005, citat în Koster și Rai, 2008, p.134).

On future relations between India and China, opinions are divided. Thus, John Garver, from Georgia Institute of Technology, USA, believes that they have fundamentally antagonistic relationship where conflict is inherent (Garver, 2004, citat în Bottelier, 2007:132).

India and China have much to learn from each other and the existing potential for the two countries to cooperate on trade and investment has been barely tapped. In many areas the two countries are fierce rivals, but in many others there is always room for cooperation. The world would be a more peaceful place if these two Asian giants would learn to work together (Ramesh, 2005). There is no reason to fear that "Chindia" will dominate the world, as both countries have to solve national problems such as poverty, unemployment and underdevelopment, which will be a challenge for the upcoming decades. In addition, none of these two countries tooth lacked aggressiveness internationally throughout history. Both have wisdom and a strong desire to maintain peace and stability. In addition to that, none of these two countries were aggressive throughout history. Both have wisdom and a strong desire to maintain peace and stability (Bottelier, 2007:133). Leaders of both countries have discussed creating a joint Chinese-Indian model based on the European Union. Although currently only an idea, if realized, this will be the largest in the world economic system, host to about 2.5 billion consumers.

\section{Instead of conclusion}

Perhaps it is pretty hard to believe that U.S. supremacy in the world is threatened. American unilateralism has been determined by the dominance of the U.S. on several fronts: military, 
economic, technological and cultural. Those were the criteria, according to Zbigniew Brzezinski, for a country to represent a truly global superpower (Revel, 2004). U.S. was the first in history to have met all these criteria. Maybe that's why is it so hard to believe that the situation will change. But historical experience shows, however, that the sequence is normal, whereas Spain and Portugal, the Netherlands, France, Great Britain have each dominated the World..

An important aspect regarding the battle for world supremacy was revealed during the last decades: the growing importance of economics in international relations. Related to this, Silviu Brucan stated: "During the Cold War the main conflict was political and military, with ideological roots between East and West. With the collapse of the Soviet Union, political and military confrontation has lost its ideological virulence and, on the international scene, economical and technological competition became the main type of conflict for winning the biggest slice of world market, military rivalry going into the background." (Brucan, 2005, p. 105)

And both India and China begin to size bigger and bigger slices of global market. After economic reforms in 1978 (in China) and 1991 (in India), they began their fulminating economic journeys. I do not think that the importance of these reforms can be argued, as well as the importance of trade liberalization which contributes to development through numerous channels. Moreover, both India and China have been less affected by the current economic crisis, compared with Europe or the U.S., and they both continue to register high growth rates. It may seem that the end of American supremacy, at least economically, is close.

With the economic importance of countries with emerging economies, they will not more be excluded from international political decisions. As it could be seen in the section on international political relations, India takes an important role, having a strong word in the issue of Iran. Furthermore, India assumed the role of representing developing countries through the creation of IBSA. But if it claims to be a world power, India will need to assume certain responsibilities. An example is the reduction of carbon emissions. If India joins the Kyoto Protocol will have to commit to a $30 \%$ reduction in emissions over the next 35 years. To maintain current national welfare, it will cause an annual cost of $\$ 280$ billion over the next 35 years (Murthy, Panda and Parikh, 2007:104105). So far, India is the second world polluter, after China (Hayward, 2009). Since they are still considered to be developing countries they have not joined the Kyoto Protocol, which would have required certain commitments that would have affected their international competitiveness

Economic statistics indicate an extraordinary boom in India, especially after the 1991 reforms. We don't think this is the main danger threatening the US domination. Unlike China, which is seen as the main rival, it seems that India is a smarter player. After the reforms and concerns about the education system, apparently India has found a truly way to threaten US domination, and not just economically. The solution is based on using the main resource they own, and what else could it be, if not people? Human capital accumulation is one of the main paths to development and the Indian 
Ministry of Education is in accordance with this objective, aiming to increase the number of educated people without diminishing the quality of education. But India is on track, holding a relatively educated labor force, which allowed the development of industries with a high level of technology and ability to provide a wide range of services. I think the future of India's international status will depend on the extent to which they will be able to facilitate human capital accumulation at a high level, by providing a quality education to an increasingly part of the population. The importance of education and research in the development process is not new. But India is one of the developing countries that have managed to put into practice one of the developing channels. In addition, India's economic growth can allow the necessary infrastructure and technology in order to create some large research centres.

\section{Bibliography}

EximBank, (2008). Global Output \& Trade - Trends (Percent Change),

http://www.eximbankindia.com/glo-eco.pdf [Accessed on January 2011]

Agrawal:(Februarie 2007) - „From Kothari Commission to Pitroda Commission”, Economic and

Political Weekly:554-557,

http://www.csc sarchive.org:8081/MediaArchive/education.nsf/1105fec5535ec8ab6525698d00 258968/08941c1079b6694a8825748a006e2b60/\$FILE/A0355611.pdf, [accessed on May 2010]

Guha, A. și Amit S. Ray (2004) - „India and Asia in the World Economy: The Role of Human Capital and Technology”, International Studies, vol. 41: 299-313;

Bhatt, P.R. (2008) - „India's Trade Competitiveness and Exchange Rate Policy”, Margin: The Journal of Applied Economic Research, vol. 2:247-265;

Bottelier:(2007) - „India's Growth from China's Perspective”, Margin: The Journal of Applied Economic Research, vol. 1, No. 1:119-138;

Feigenbaum, E. (2008, 7 April) - „Strategic Context of US-India Relations”, Briefing to Harvard University Weatherhead Fellows, Washington, DC, http://merln.ndu.edu/archivepdf/india/State/103809.pdf, [accessed on May 2010]

Friedman, T. (2007) - Pământul este plat. Scurtă istorie a secolului XXI, Editura Polirom, București, 2007:113;

Global Finance Magazine, Country Economic Reports \& GDP Data, www.gfmag.com, [accessed on May 2010]

Hayward, S. F. (2009) - Index of Leading Environmental Indicators 2009, Pacific Research Institute, San Francisco, California, US A, 
http://www.pacificresearch.org/docLib/20090414_Env_Index_09.pdf, [accessed on May 2010]

Hirst, M. (2008) - „Brazil_India Relations: A Reciprocal Learning Process”, South Asian Survey, vol. 15, No. 1:143-164;

Jaffrelotm, C. (2009) - „The India-US Rapprochement: State-driven or Middle Class-driven?”, India Quarterly: A Journal of International Affairs, vol. 65, No. 1:1-14;

Koster, S. și Rai, S. K. (2008) - „Entrepreneurship and Economic Development in a Developing Country: A Case Study of India”, Journal of Entrepreneurship, vol. 17:117-137;

Kothari Commission Report (1966), Education Commission, 1964-66/Dr.D.S. Kothari

Commission, Government of Ind ia Ministry of Human Resource Development, Department of Education and National Informatics Centre-Compilation on 50 years of Indian Education, 1947-1997, www.education.nic.in/cd50years/g/T/H5/0TH50501.htm, [accessed on May 2010]

Krugman, Paul (2007) - World Affairs Council of Northern California, San Francisco, California, http://fora.tv/2007/09/11/Paul_Krugman_Conscience_of_a_Liberal, [accessed on May 2010]

Murthy, N. S., Panda, M. și Parikh, K. (2007) - „CO2 Emission Reduction Strategies and Economic Development of India", Marg in: The Journal of Applied Economic Research, vol. 1:85-119; Narasimharao, B.P. (2009) - „Knowledge Economy and Knowledge Society Role of University Outreach Programmes in India”, Science Technology Society, vol. 14:119-151;

Park, J. H. (2002) - „The Two Giants of Asia: Trade and Development in China and India”, Journal of Developing Societies, vol. 18:64-83;

Pitroda, S. (2007) - Communication to delegates CALIBER (Convention on Automation of Libraries in Education and Research), Chicago, The Fifth Edition of International Conference CALIBER, 2007 organized by INFLIBNET Centre, Ahmedabad in collaboration with Panjab University, Chandigarh, 9-10 February 2007;

Ramesh, J. (2005) - „Making Sense of Chindia: Reflections on India and China”, India Research Press, New Delhi, 2005;

Revel, J. F. (2004) - “Obsesia antiamericană”, Editura Humanitas, București, 2004;

Samantaraya, A. şi Verrier, J. (2009) - „Do Macroeconomic Indicators Explain India's Sovereign Ratings? An Empirical Analysis", Marg in: The Journal of Applied Economic Research 3:3; pp. 193-221;

Silviu, S. (2005) - „Scolul XXI: Viitorul Uniunii Europene, Războaiele în secolul XXI”, Editura Polirom, București, 2005;

Singh, B. (2009) - „Structural Shifts in the Current Account of India's Balance of Payments”, Margin: The Journal of Applied Economic Research, vol. 3:133-171; 
*** The World Factbook, https://www.cia.gov/library/publications/the-worldfactbook/geos/in.html, [accessed on May 2010] 